Hakemli

\title{
GARANTİ VE KEFALET SÖZLEŞMELERİ ARASINDAKI AYRIM
}

\author{
The Differences Between Surety and Indemnity Contracts
}

\section{Gökhan ÇINAR*}

\section{ÖZ}

Garanti ile kefalet sözleşmeleri kişisel teminat sözleşmelerinin bir türüdür. $\mathrm{Bu}$ sözleşmenin tarafı olan alacaklı, borç ifa edilmediği takdirde güvence verene başvurma imkânı kazanır. Kefalet sözleşmesi Türk Borçlar Kanunu'nda (TBK) açikça düzenlenmişken, garanti sözleşmesi ancak TBK'nın 128. maddesi ve içtihatlar ışı̆̆ında yorumlanabilmektedir. Uygulamada ve teoride bu iki sözleşmenin ayrımını yapmak her zaman kolay olmamıştır. "Aslilik- fer'ilik", "yorum" ve "taraf iradeleri” gibi ölçütler bu hususta yol göstericidir. Tüm bunların yanında yasa koyucu, TBK'nın 603. maddesiyle kefalet sözleşmesinin kefili koruyucu yanlarının bertaraf edilmesi çabasının da önüne geçmek istemiştir. Bu mecburiyet özellikle bankacılık faaliyetlerinde, borca güvence veren gerçek kişilerin uğradıkları mağduriyetten doğmuştur. Daha önce yargı kararlarıla yapılan yorum, bu şekilde kanuni zemine oturtulmuştur.

Anahtar Kelimeler: Türk Borçlar Kanunu, garanti sözleşmesi, kefalet sözleşmesi, kıstaslar, içtihat

\section{ABSTRACT}

Surety and indemnity contracts are a kind of personel assurance contracts. In case of nonperformance of the debt, the creditor, as the party of this contract obtains the opportunity to apply to assurance giving party. Whilst

Makalenin Geliş Tarihi: 25.05.2020, Makalenin Kabul Tarihi: 05.06.2020

Ankara 2. Ağır Ceza Mahkemesi Hâkimi, Ankara Üniversitesi Sosyal Bilimler Enstitüsü Özel Hukuk ABD Doktora Öğrencisi, gokhan_cinar058@hotmail.com, ORCID: 00000001-8958-1371 
surety contract is regulated obviously in Turkish Code of Obligations (TBK), indemnity contracts shall just be interpreted in the light of Art. 128 of TBK and the judicial precedents. In practice and theory, drawing a certain line between this type of contracts is not so easy every time. The criteria like "principal-secondary", "interpretation" and "the wills of the parties" are leading in this case. In addition to these, the legislator has aimed to counteract the endeavor of eliminating the surety contract's sides that protect the surety via Art. 603. This compulsion has arised from the mischief of the individuals who gave assurance in banking business. Thus, this interpretation made by judicial precedents, has been seated on the statutory ground.

Keywords: Turkish Code of Obligations, indemnity contract, surety contract, criteria, precedent

\section{GíRiş}

$\mathrm{Bu}$ çalışmanın amacı iki farklı kişisel teminat olan kefalet sözleşmesi ile garanti sözleşmesi arasındaki benzerlik ve farklılıkları ortaya koymaktır. $\mathrm{Bu}$ sözleşmelerle bir kimse, kefil veya garanti veren, bir diğer kişiye, garanti alana, muhataba, üçüncü bir şahsın, asıl borçlunun (garanti emrini verenin, lehdarın) yine alacaklıya karşı hukuki bir ilişkiden, asıl sözleşmeden (alt sözleşmeden, temel borç ilişkisinden) doğan borcunu ifa edeceğini taahhüt eder. Ekonomik hayatta her iki sözleşmenin de uygulama alanı oldukça geniştir ve benzer rolleri sebebiyle teminat sözleşmesi kapsamında yapısal olarak büyük bir ayniyet içindedirler. Oldukça teorik olan bu vasıflandırma zorluğu uygulamada da ciddi sorunlara sebep olmuştur. Her iki sözleşmenin ayırt edilmesindeki zorluğun en büyük sebeplerinden biri de, ekonomik fonksiyonlarının neredeyse aynı oluşudur. Her ikisinde de amaç bir kimsenin malvarlığındaki azalma riskini ortadan kaldırmaktır. Hem kefil hem de garanti veren asıl borçlunun yanında sanki yeni bir borçlu statüsündedir.

\section{I- BİR TEMINAT TÜRÜ OLARAK GARANTI VE KEFALET KAVRAMLARI}

Öncelikle teminat kavramını açıklamak gerekir.

Teminat sözleşmelerindeki temel amaç borçlunun, âkit diğer tarafin zarar rizikosunu üstlenmesidir. ${ }^{1}$ Teminat, ayni ve kişisel teminat olarak iki grupta incelenebilir. Ayni teminatın konusu prensip olarak taşınır veya taşınmaz bir

1 YAVUZ, Cevdet, Borçlar Hukuku Özel Hükümler, İstanbul, 2016, Beta Yayıncılık, s. 775 
mal veya haktır. Ayni teminatla borçlu malvarlığındaki belirli bir şeyi borcunun garantisi olarak özgüler ve alacaklıya o şey üzerinde bir ayni hak (özellikle rehin hakkı) tanır. Eğer teminat konusu bir taşınmaz ise taşınmaz rehininden, taşınır ise taşınır rehininden bahsedilir. Ayni teminatlar açısından "numerus clausus" ilkesi geçerlidir. Kişisel teminat ise teminat alacaklısına bir şey üzerinde ayni bir hak vermez, sadece bir alacak hakkı, alacaklının şartlar oluştuğu takdirde talep edeceği bir kişisel hak verir. Kişisel teminatta bir veya birden fazla kişi, asıl borçlunun yükümlülüğüne ek olarak yükümlülük altına girerler. Kişisel teminat asıl borçlunun borcunu güvence altına almak amacıyla üçüncü şahsın yükümlülük altına girmesi olarak tanımlanmaktadır. Kefalet ve bağımsız garanti sözleşmesi, alacaklıya asıl borçlu borcunu ifa etmediği, gereği gibi ifa etmediği veya zamanında ifa etmediği hallerde güvence verene başvurma hakkı tanıyan kişisel teminatlardandır. ${ }^{2}$

Garanti sözleşmesi çeşitli türleri olup homojen olmayan bir sözleşme türüdür. Farklı türleri söz konusu olsa da tüm garanti sözleşmelerinin ortak noktası, garanti verenin garanti alanın karşılaşması muhtemel rizikosunu üzerine almasıdır. ${ }^{3}$

Teminat sözleşmelerinden olan garanti sözleşmesi, Kanun tarafından düzenlenmemiş olmakla beraber günümüzde banka teminat mektupları şeklinde geniş bir uygulama alanına sahiptir. Türk Borçlar Kanunu'nda (TBK) sadece belli bir garanti sözleşmesi türü olan başkasının fiilini taahhüt, eksik bir şekilde TBK'nın 128. maddesinde hükme bağlanmıştır. ${ }^{4}$

Garanti sözleşmesi ile garanti veren, garanti alandan bir ivaz karşıllı̆ında değil, yalnızca onu bir teşebbüse yönlendirmek amacıyla bağımsız şekilde, teşebbüsün riskini üzerine alır. ${ }^{5}$

İncelememize konu olan "kefalet benzeri garanti sözleşmesi", bir borcun konusunu oluşturan edimin ifasının, bu borcun varlığı, dava edilip edilemeyeceği gibi hususlardan bağımsız olarak güvence altına alındığı bir sözleşme türüdür. Bu tanımdan da anlaşılacağı üzere "borç" değil "borcun konusunu oluşturan edim" kavramı ön plana çıkmaktadır; yani, bir "sonuç" taahhüdü söz konusu olmaktadır. ${ }^{6}$

2 DEVELIOĞLU, Hüseyin Murat, Kefalet Sözleşmesini Düzenleyen Hükümler Işıı̆ında Bağımsız Garanti Sözleşmeleri, Vedat Kitapçılık, İstanbul, 2009, s.11-12

3 ÖZEN, Burak, Kefalet Sözleşmesi, Vedat Kitapçılık, İstanbul 2014, s.23

4 REISOĞLU, Seza, Türk Kefalet Hukuku, Ankara, 2013, s.121

5 REİSOĞLU, Seza, Garanti Mukavelesi, Ajans-Türk Matbaası, Ankara, 1963, s.9

6 ÖZEN, s.25 
TBK'nın 128. maddesi parasal bir riski güvence altına alma imkânlarından biri olarak düzenlenmiştir. Garanti sözleşmesi, geniş anlamda teminat işlemleri arasında yer almaktadır. Garanti ve kefalet kişisel güvence türlerindendir. Garanti sözleşmesinde garanti veren garanti alana bir üçüncü kişinin edimini eda edeceğini taahhüt eder. Garanti sözleşmesi ile garanti verene yabancı bir eda güvence altına alınır. ${ }^{7}$ Belirtmek gerekir ki, önceki 818 sayılı BK 110. maddesinde düzenlenen "başkasının fiilini taahhüt" ifadesi yerine daha doğru anlamı verecek şekilde yeni BK'da 128. maddede, madde başlığı olarak "üçüncü kişinin fiilini üstlenme" ibaresi kullanılmıştır. Garanti veren, garanti alana, üçüncü bir kişinin garanti alana karşı gerçekleştireceği bir davranışı bağımsız bir sözleşme ile vaat eder ve vaat edilen bu davranış gerçekleşmezse garanti veren, garanti alana uğradığı zararı tazmin borcu altına girer. Garanti veren kendisinin edada bulunmasını değil, tam tersine üçüncü kişinin belirli veya belirlenebilir bir davranışını vaat etmektedir. Garanti verenin bu sözleşmedeki edimi, üçüncü şahıs edimini yerine getirmediğinde garanti alanın zararını tazmin etmektir. Özetle TBK'nın 128. maddesi, üçüncü kişinin edimini ifa etmemesi durumunda garanti alan tararından garanti verene yöneltilebilecek bir tazminat istemini düzenlemektedir. Garanti veren üçüncü kişinin bu edasını kendi adına ve kendi hesabına taahhüt eder; yani, üçüncü kişinin temsilcisi değildir. Üçüncü kişi sözleşmenin tarafi değildir veya garanti sözleşmesi ile kendiliğinden sözleşmenin bir tarafi haline gelmez. Bu sözleşme ancak garanti alan ve veren arasında hüküm doğurur. Bu sebeple garanti sözleşmesi, örneğin üçüncü kişinin hukuki işlem ehliyetinin olmamasından veya gerçekte herhangi bir sebeple borçlu olup olmamasından etkilenmez. Garanti sözleşmesiyle üçüncü kişi yükümlülük altına sokulamaz. ${ }^{8}$

\section{II- 6098 SAYILI TÜRK BORÇLAR KANUNU'NUN 603. MADDESI ILE KEFALET HÜKÜMLERININ UYGULAMA ALANININ GENIŞLETILMESI}

818 sayılı eski Borçlar Kanunu'nda (BK) gerçek kişilerce, kişisel güvencelerin başka ad altındaki sözleşmelerle verilmesi durumunda, kefalete

7 KOCAMAN, Arif, Yargitay Hukuk Genel Kurulunun 4/7/2001 Tarih ve E.2001/19-534, K.2001/583 Sayılı Kararı Üzerine Bir Değerlendirme- Kredi Kartı İlişkisinde Bankaya Karş1 Verilen Kişisel Teminatın Hukuki Niteliği: Garanti mi; Kefalet mi? Ticaret Hukuku ve Yargitay Kararları Sempozyumu, XIX, 10 Mayss 2003, Ankara 2003, s.70

8 KOCAMAN, Arif, Türk Borçlar Kanunu'nun 603. Maddesi Üzerine Bir DeğerlendirmeKefalete İlişkin Hükümlerin Uygulama Alanı, Prof. Dr. M. İlhan Ulusan'a Armağan, Seçkin Kitabevi, Cilt 3, s.487-488 
ilişkin hükümlerin uygulanacağına dair bir hükme yer vermemişti. Yeni Kanun'da buna ilişkin bir düzenleme yapılmıştır: 603. madde. Buna göre: "Kefaletin şekline, kefil olma ehliyetine ve eşin rizasina ilişkin hükümler, gerçek kişilerce, kişisel güvence verilmesine ilişsin olarak başka ad altında yapılan diğer sözleşmelere de uygulanır."

Kefalet sözleşmesinde kefili koruyan ayrıntılı düzenlemelerin bertaraf edilmek istenmesi, güvence verenin sorumlu olacağı borcun gösterilmesi gerekliliği olmayan, garanti sözleşmesi şeklinde kişisel teminat sözleşmeleri yapılmasına yol açmıştır. ${ }^{9}$

Kefalet ile garanti sözleşmelerini birbirinden ayırmadaki en önemli ölçütlerden biri olan "aslilik-fer'ilik" ölçütünü etkisizleştirme, kefalet ve garanti kurumlarını birbirlerine yaklaştırma, kefaletin koruyucu niteliğini bertaraf edeceği cihetle bankalar lehinedir. Evvelce Yargitay kararları ile destek bulan "kefalete ilişkin hükümlerin uygulama alanının genişletilmesi" eğilimi, TBK'nın 603. maddesinin yürürlüğe girmesiyle yasal bir dayanak kazanmıştır. Dolayısıyla anılan yargı kararları varken TBK'nın 603. maddesi önceden yaşanan hukuksal sorunlar ve zayıfların korunması ihtiyacı, kanun koyucuyu tepkisel bir yaklaşımla anılan maddeyi ihdas etmesini sağlamıştır. ${ }^{10}$ Öğretide kimileri tarafından TBK'nın 603. maddesinin gereksiz olduğu savunulmuştur. Örneğin Reisoğlu, "Hukuk Genel Kurulunun 2001 tarihli kararında ve bunu takiben diğer Yargitay özel daire kararlarında, garanti altında atılan imzalarla, aslında bir kefaletin kastedildiği kabul edilmektedir. Bu kararlarda asli yükümlülük oluşturan garanti sözleşmelerine de kefalet hükümlerinin uygulanacağı ileri sürülmemektedir. Ancak bu durumda kararlar ne kadar eleştirilse eleştirilsin- yeni bir madde kabulüne gerek bulunmamaktaydl."11 şeklinde görüş belirtmişse de, ülkede bankaların uygulamaları ve benzer uyuşmazlıkların çokluğu dikkate alındığında bu görüşe katılmak güç görünmektedir. Kaldı ki TBK'nın 603. maddesi tarafların garanti sözleşmesi yapmasını engellememektedir. Bunun yanında tek taraflı hazırlanmış genel kayıtlar içeren ve âkit tarafa başka imkân bırakmayan şablon sözleşmelerin, serbest iradeyle ortaya çıkartılmış bir garanti sözleşmesi niteliğinde olduğundan bahsetmek mümkün değildir. Hal böyle iken hukuk düzeninin ihtiyatlı davranması kaçınılmazdır. ${ }^{12}$

9 ÇEKER, Mustafa, "Tüketicinin Korunması Hakkında Kanun Kapsamında Kredi Kartı Borcunun Ödenmemesi ve Hukuki Sonuçları", Atatürk Üniversitesi Hukuk Fakültesi Dergisi, Cilt VIII, Say1 1-2, 2004, s. 437

${ }^{10}$ KOCAMAN, 603. Maddde, s.509

${ }^{11}$ REISOĞLU, Kefalet, s.322

12 KOCAMAN, 603. Madde, s.510 


\section{III- GARANTİ SÖZLEŞMESINIIN UNSURLARI}

\section{A- Garanti Alanı Belli Bir Hareket Tarzına Yöneltmek Amacı}

Garanti veren, garanti alanı belli bir harekete sevk etmeyi amaçlayarak anılan bu hareketin zararlı sonuçlarını tazmin etmeyi üstlenir. Garanti alanın girişeceği teşebbüsün mutlaka parasal kazanca ilişkin olması gerekli değildir. Bazı durumlarda mesela bu teşebbüsle sanat veya bilimle alakalı bir amaç gerçekleştirilmek istenilse bile teşebbüsün garanti alan için parasal bir zarar doğurması rizikosu söz konusu olmalıdır. Garanti alanın bahsedilen bu hareket tarzı ise genellikle bir ticari işletme kurmak, bir anonim ortaklığın hisse senetlerini satın almak, bir gösteri düzenlemek, üçüncü kişiyle bir sözleşme yapmak gibi ortaya çıkabilir. ${ }^{13}$ Önemli husus şudur ki, garanti alan kendi girişiminin tehlikeli sonuçlarına karşı korunur; yoksa onun hukuki işlem tesis edeceği teşebbüsü, mesela hisse senetlerini alacağı anonim ortaklığg korumak değildir. Bununla beraber garanti alana güvence verilerek, bu ortaklık da hisse senetlerine daha kolay alıcı bulacağ 1 cihetle "bir teşebbüse sevk etme amacı"ndan bahsedildiğinde, bu girişimin bizzat garanti alanın, "sonucu şüpheli bir hareketi" olması zorunluluğu göz ardı edilmemelidir. ${ }^{14}$

Garanti alanı bu şekilde belirli bir harekete sevk etmek amacı garanti sözleşmesinin illetini teşkil eder. ${ }^{15}$

Garanti sözleşmesinin kumar, bahis veya sigorta ile de ayrımını ortaya koymak gerekir. Şöyle ki: Kişiyi belirli bir harekete yöneltmek amacı olmadan onun girişiminin rizikosunu ivazlı şekilde üstlenmek bir sigorta mukavelesi, kumar veya bahis niteliğinde; ivazsız şekilde üstlenme ise şarta bağlı bir bağışlama niteliğindedir. ${ }^{16} \mathrm{Bu}$ şekildeki şartlı bağışlamaya örnek olarak şu verilebilir: Fakir bir ayakkabı tamircisine yardımda bulunmak isteyen zengin birinin, tamirciye dönemsel olarak tamircinin kazancı belli bir tutarı bulmazsa, açığını kapatmayı temin etmesinde olduğu gibi şartlı bir bağışlama söz konusudur. ${ }^{17}$

\footnotetext{
${ }^{13}$ REİSOĞLU, Garanti Mukavelesi, s. 17-18

${ }^{14}$ TANDOĞAN, Haluk, Borçlar Hukuku, Özel Borç İlişkileri, Cilt II, Vedat Kitapçılık, İstanbul 2010, s.811

${ }^{15}$ REİSOĞLU, Garanti Mukavelesi, s.18

${ }^{16}$ REISOĞLU, Garanti Mukavelesi, s.19

17 TANDOĞAN, s.811
} 


\section{B- Garanti Alanın Hareket Tarzından Doğacak Tehlikenin Üstlenilmesi}

Garanti veren, garanti alanı belli bir davranıșa yönelterek onun alacaklı olarak bir borç ilişkisine girmesini güvence altına almak adına, bu davranışından veya borç ilişkisinden doğacak riskleri üstlenir. Bu risk, garanti alanın sözleşme yaptığ 1 edimi, garanti edilen üçüncü kişinin sözleşmeyi gereği gibi yerine getirmemesi sebebiyle garanti alanın uğraması muhtemel zarar olabileceği gibi, bahse konu girişiminin beklenen kârı sağlamaması veya zararlı bir sonuç şeklinde ortaya çıkması da olabilir. ${ }^{18}$

Bu güvence, rizikonun tamamına şâmil olabileceği gibi sadece belirli bir zararın ortaya çıkmayacağı veya belirli bir olayın gerçekleşeceği şeklinde güvence verilmesi şeklinde olabilir. Yine kısmen tehlike üstlenilmesi de mümkündür. Tehlikenin kapsamına kaza ve beklenmeyen durum da girer. Bunun yanında tehlike, garanti alanın kusuru olmadan artmışsa ve bu tehlike girişimin niteliğine ve gayesine uygunsa garanti veren artan bu rizikodan yine sorumludur. ${ }^{19}$

\section{C- Bağımsız Yükümlülük Altına Girme}

Bağımsız yükümlülük altına girmek, garanti verenin yükümlülüğünün başka bir borcun varlığına, geçerliliğine, yasal takip yapılabilir olup olmadığına bağlı olmamasıdır. ${ }^{20}$

\section{D- İvazsızlık}

Garanti sözleşmesi kural olarak tek tarafa borç yükler ve ivazsızdır. Yalnızca garanti veren bir yükümlülük altına girer. Anılan riskin üstlenilmesindeki amaç, garanti alandan bir ivaz elde etmek değil ve fakat girişimin gerçekleşmesidir. Garanti alanın güvenceyi kabul etmesi garanti alanı asla yükümlülük altına sokmaz. Garanti alanın girişimle ilgili birtakım yükümlülükler altına girmesi sözleşmenin vasfinı değiştirmeyecektir. Örneğin, garanti verenin garanti alana teşebbüsün belirli bir şekilde teşkilatlanmasını istemesinde olduğu gibi. Bu gibi durumlarda, sözleşmenin kurulması sırasında garanti alanın birtakım yükümlülükleri kabul etmesi, garanti sözleşmesinin niteliğini değiştirmeyecektir. Çünkü bu türden yükümlülükler genellikle karşı edaya karşılık gelecek bir değer taşımamaktadır. Bu tür durumlarda genel bir kuraldan bahsetmek zor olduğu cihetle, garanti verenin taahhüdü ile garanti alanın yükümlülüğü arasındaki ilişki sözleşmenin niteliğini belirleyecektir. ${ }^{21}$

18 TANDOĞAN, s.811

${ }^{19}$ REİSOĞLU, Garanti Mukavelesi, s.12-13

${ }^{20}$ REİSOĞLU, Garanti Mukavelesi, s. 19-20

${ }^{21}$ REISOĞLU, Garanti Mukavelesi, s.22 


\section{IV- GARANTI SÖZLEŞMESININ ÍKILII AYRIMI}

Garanti sözleşmesinin başlıca iki türü vardır. Bunlardan biri "saf garanti”" veya aynı anlamda kullanılan "yönlendirmeyi amaçlayan garanti sözleşmesi" ve diğeri ise, "kefalet benzeri garanti" veya aynı anlamda kullanılan "teminat amaçlı garanti" sözleşmesidir. ${ }^{22}$ Saf garanti sözleşmesinde, garanti veren başka bir sözleşmeye bağlı olmaksızın bir sonucun ortaya çıkmasını temin eder. ${ }^{23}$ Bankanın garanti veren sıfatıyla bir işletmenin kaybını kapatacağına dair güvence vermesindeki gibi. Bu örnekte üçüncü kişilerin anılan işletme ile borç ilişkisi içine girip girmeyecekleri belli değildir; yani, kesin olmayan bir olay söz konusudur. Bu tür sözleşmede garanti veren, garanti alanı belirli bir şekilde hareket etmeye yönlenmektedir. ${ }^{24}$

Saf garanti (yönlendirmeyi amaçlayan garanti) sözleşmelerine örnek olarak, A'nın B'yi C'ye karşı dava açmaya sevk etmek için onun davayı kaybetmesi ihtimalinde, yargılama giderlerini kendisinin ödeyeceğini güvence altına alması; Roma Hukuku'nda bir annenin, oğlunun vasisini bir üçüncü kişiye karşı oğlu adına dava açmaya sevk etmek için,, davanın kaybı halinde yargılama giderlerini ödeyeceğini güvence altına alması; garanti verenin garanti alanı yabancı kanuna aykırı bir döviz alım satım yapmaya sevk etmek için bunun risklerini üzerine alması; garanti verenin garanti alanın bir fabrika projesini finanse etmesi için bu projenin gerektirdiği su imtiyazlarının elde edileceği hususunda garanti vermesi gösterilebilir. ${ }^{25}$

Buna karşıllk kefalet benzeri garanti sözleşmesinde verilen güvence, garanti alan ile edimi temin edilen üçüncü kişi arasında bir sözleşme ile bağlantılıdır. ${ }^{26}$ Kefalet benzeri garantide üçüncü kişinin gerçekte borçlu olup olmadığının önemi yoktur; garanti veren yine de üçüncü kişinin edimini garanti eder. Hatta kefalet benzeri garantide üçüncü kişi ile garanti alan arasındaki borcun aslında hiç doğmadığı, ortadan kalktığı veya yasal takibinin yapılamadığı durumlarda da verilen güvence geçerlidir. Kefalet benzeri garanti sözleşmesinde garanti alanla üçüncü kişi arasında geçerli bir temel ilişki aranmaz. Temel işlemin sahteliği veya imkânsızlığı garanti sözleşmesinin geçerliliğ̈ini etkilemez. ${ }^{27}$

22 İŞGÜZAR, Hasan, Banka ve Kredi Kartı Sözleşmeleri, Yetkin Yayınları, Ankara, 2003, s. 197

23 BARLAS, Nami, "Kredi Kartı İlişkisinde Bankaya Karşı Verilen Teminatın Niteliğinin Belirlenmesi”, Ömer Teoman'a 55. Yaş Günü Armağanı, Cilt III, İstanbul, 2002, s. 948

24 KOCAMAN, Garanti mi; Kefalet mi? s.72

25 TANDOĞAN, s.804

26 EREN, Fikret, Borçlar Hukuku Özel Hükümler, Yetkin Kitabevi, Ankara, 2009, s.779

27 KOCAMAN, Garanti mi; Kefalet mi? s.72 
Kefalet benzeri garanti ile saf garanti sözleşmeleri arasındaki diğer farklar şöyledir:

Kefalet benzeri garantide garanti alan ile edimi garanti edilen arasında bir temel ilişki, bir borç ilişkisi vardır; fakat garanti verenin güvencesinin geçerliliği bu borç ilişkinin geçerli olup olmamasına, varlığına bağlı değildir. Saf garanti sözleşmesinde ise garanti alan ile edimi vaat edilen üçüncü kişi arasında henüz bir borç ilişkisi yoktur. Örneğin, düzenlenmesi istenilen bir fuarın, tiyatro oyununun gelecekteki ziyaretçileri veya seyircileri ile tertip komitesi veya işletici arasında, kasabanın hastaları ile kar garantisi verilen eczacı arasında, sayılan birinci kişileri, edimde bulunmaya zorlayacak bir borç ilişkisi. Saf garanti verenin borcu bu haliyle edimi garanti edilenin borcundan tamamen bağımsızdır. Kefalet benzeri garantide güvence sağlamak ön plandadır. Bu sebeple garanti veren, edimini garanti ettiğinden veya garanti alandan bir komisyon (Komisyon taraflar arasındaki temel borç ilişski üzerinden alınmaz, garanti verenle âkit taraf arasındaki sözleşmeye istinaden alınır.) alır; fakat saf garanti sözleşmesinde garanti verenin garanti alanı belli bir davranışa yönlendirmek şeklindeki bir yararı ön plandadır ve garanti veren garanti için bir komisyon almaz. ${ }^{28}$

Kefalet benzeri garanti sözleşmesinde de garanti verenin, garanti alanı edimi için güvence verilen üçüncü kişiyle borçlandırıcı bir sözleşmeye yönlendirdiği düşünülebilir; fakat saf yani yönlendirici garanti sözleşmesinde üçüncü kişinin edimi her zaman temin edilmeyebilir veya edimi garanti edilen üçüncü kişiler de her zaman belirli değildir. ${ }^{29}$

Kefalet benzeri garanti sözleşmesinin "alacağın garanti sözleşmesi" şeklinde adlandırılması da doğru değildir; çünkü garanti edilen bazen varlığı bile belli olmayan alacak değil, üçüncü kişinin edimidir. ${ }^{30}$

Banka teminat mektupları asıl borçlunun (lehdarın) defilerinden feragat kaydını taşıdığ 1 takdirde genellikle kefalet benzeri garanti sözleşmesi olduğu kabul edilir. ${ }^{31}$

28 TANDOĞAN, s.808

${ }^{29}$ TANDOĞAN, s.809

${ }^{30}$ TANDOĞAN, s.805

31 TANDOĞAN, s.805 


\section{V- GARANTİ SÖZLEŞMESININ KEFALETTEN AYIRT EDILMESİ}

Aslında kefalet sözleşmesiyle burada kıyaslanan "kefalet benzeri garanti" sözleşmesidir. Çünkü kefalet benzeri garanti sözleşmesinde de tıpkı kefaletteki gibi bir "temel işlem" vardır ve garanti veren bu temel işlemi güvence altına almak için bu sözleşmeyi yapar. Kefalet benzeri garanti sözleşmesinde garanti alan, garanti veren ve üçüncü kişi; kefalet sözleşmesinde ise kefil, alacaklı ve asıl borçlu yer almaktadır. ${ }^{32}$

Garanti sözleşmesi benzer sözleşme türlerinden ayırt edilmesi zor bir tür olduğu cihetle gerek doktrin gerekse yargı kararlarında çokça yer almış ve tartışmalara sebep olmuştur. Kefalet ve garanti sözleşmelerini birbirinden ayırt etmeye yarayan kriterler noktasında ciddi görüşler bulunmaktadır. 818 sayılı BK m.485/3.cümlenin ve 6098 sayılı TBK m.582/2'deki düzenleme uyarınca, hata ve asıl borçlunun ehliyetsizliği sebebiyle bağlayıcı olmayan bir sözleşmeden doğan borca kefil olan kimse, bu yükümlülüğünü üstlendiği sırada bu eksikli biliyor idiyse, burada "kefalet benzeri garanti" söz konusu olmasına rağmen ancak madde hükmü uyarınca kefalet hükmü uyarınca yükümlü olabilir. Bu maddeyle, her iki sözleșme türünü birbirinden ayırt etmeye yarayan temel ölçütlerden biri olan "aslilik/fer'ilik" ölçütü geçerliliğini korumuştur. TBK 603. Maddesi ile kefaletin daha çok alanda uygulanmasının önü açılmış, özellikle bankalar yararına ortaya çıkan "kefalet" ve "garanti” sözleşmeleri arasındaki ayırt edici ölçütleri etkisizleştirme eğiliminin önü kapatılmıştır. Bu şekilde Yargıtay HGK'nın 04/07/2001 gün, 2001/19-534 Esas ve 2001/583 Karar say1l ilamındaki görüşe mevzuatta bir destek sağlanmıştır. ${ }^{33}$

Kefalet ve garanti sözleşmesinin ayırt edilmesindeki pratik sonuç güvence verenin sorumluluğu açısından büyük önem arz eder. Kefalet benzeri garanti sözleşmesine gerek duyulmasının sebebi kefaletin fer'i nitelikte olmasına rağmen kefalet benzeri garanti sözleşmesinde garanti verenin asıl borçtan bağımsız olarak asli nitelikte yükümlü olmasıdır. ${ }^{34}$

Her iki sözleşmenin ayırt edilmesi sırasında ilk fark edilen husus şudur ki, garanti sözleşmesinin niteliği TBK'nın 128. Maddesi ışığında açıklığa kavuşturulabilirken, kefalet sözleşmesi TBK'da ayrıntılı şekilde düzenlenmiştir. ${ }^{35}$

\footnotetext{
${ }^{32}$ KOCAMAN, Garanti mi; Kefalet mi? s.72

${ }^{33}$ KOCAMAN, 603. Madde, s. 485

${ }^{34}$ ÖZEN, Burak, s.27

35 BİLGEN, Mahmut, Öğreti ve Uygulamada Kefalet ve Yargılama Hukukuna İlişkin Uyuşmazlıklar, Adalet Yayınevi, Ankara, 2013, s.115
} 
Kefalette asıl borçlunun kusurlu hareketiyle borcu ifa edememesi tehlikesi, asıl borcu aşmayacak şekilde karşılanırken ${ }^{36}$ kefalet benzeri garantide temel ilişkideki borcun var olup olmaması tehlikesi de karşılanmaktadır. Örneğin, nafaka borcunun mevcut olmamasına rağmen bunun garanti edilmesinde kefalet benzeri bu sözleşme geçerlidir. Bu sebeple her ne kadar kefil fer'iliğin bir sonucu olarak asıl borçlunun tüm def'ilerinden yararlanıp bunları alacaklıya ileri sürebilirse de, garanti veren asıl borçtan bağımsız garanti verdiği için asıl borçlunun def'ilerinden bazılarını, bu arada kusursuz imkânsızlık def' ini ileri sürmemeyi kabul etmiş olabilir. ${ }^{37}$ Örneğin alacaklının uluslar arası ödeme sinırlamaları dolayısıyla, asıl borcun ödenmesinin imkânsızlığı tehlikesine karşı garanti edilmesinde olduğu gibi. ${ }^{38}$ Buradan da anlaşıldığ üzere kefalet borcunun asıl borç ile bağlantılı olması sebebiyle, kefalet benzeri garanti sözleşmesinin asli nitelikte olması, alacaklı için daha güçlü bir güvence ortaya çıkarmaktadır. ${ }^{39}$

TBK'nın 582. maddesine göre kefilin sorumluluğu asıl borcun geçerliliğine bağlıyken, garanti sözleşmesi asıl borçtan bağımsızdır. Yine kefil, kefaletten doğan borcunu ödemesini müteakiben TBK'nın 596/1. maddesine göre yasadan kaynaklı rücû hakkını kullanabilir. ${ }^{40}$ Oysa garanti verenin böyle bir hakk1 yoktur. ${ }^{41}$ Ayrıca, adi kefalette kefilin sorumluluğuna gidebilmek için önce asıl borç için takip başlatılması ve takibin semeresiz kalması gerekirken ${ }^{42}$, garanti sözleşmesinde garanti alan, garanti verenin vaat ettiği üçüncü kişinin edimi yerine getirilmediğinde derhal garanti verene başvurabilir. ${ }^{43}$

Kefalet de garanti sözleşmesinde olduğu gibi bir başkasının karşı karşıya kaldığı rizikoyu üstlenmeyi gerektirir. Kefil asıl borçlu yerine ifayı

36 GÜMÜS, Alper, Borçlar Hukuku Özel Hükümler, Cilt II, İstanbul, 2014, s. 323

37 KAHYAOĞLU, Emin Cem, Banka Garantileri, İstanbul, 1996, Beta Yayınları, s. 31

38 TANDOĞAN, s.805

39 ACAR, Özlem, Türk Borçlar Hukukunda Müteselsil Kefalet Sözleşmesi, XII Levha Kitapçılık, s.38

40 ARAT, Ayșe, "Tüketici Hukukunda Kefalet Sözleșmesi”, Selçuk Üniversitesi Sosyal Bilimler Meslek Yüksekokulu Dergisi, Cilt 19, s. 210

41 DOĞAN, Vahit, Banka Teminat Mektupları, Ankara, 2005, Seçkin Yayınları, s. 57

42 AYBAY, Aydın, "Kefilin Önce Dava Def'ini İleri Sürmesi Sorunu”, Prof. Dr. Selim Kaneti’ye Armağan, İstanbul, 1996, s. 83; BİLGE, Necip, Borçlar Hukuku Özel Borç Münasebetleri, Ankara, 1971, s.375

Ayrıca "Peşin dava def'i" veya diğer adıyla "tartışma def' $i$ " için bkz. ZEVKLİLER, Aydın, Borçlar Hukuku Özel Borç İlișkileri, Ankara, 2004, s. 401; ȘAHAN, Gökhan, Kefalet Sözleşmesinin Sona Ermesi, Ankara, 2009, s. 45

43 BİLGEN, s.114 
üstlenmeden ${ }^{44}$, borcun ifa edilmemesi durumunda sadece kendisinin sorumlu olduğu miktarı ödeyerek, verdiği teminattan kaynaklı borcunu ifa etmiş olur. ${ }^{45}$ Buna rağmen kefalet yine de garanti sözleşmesinin bir türü olarak kabul edilemez. ${ }^{46}$

Kefalette kefilin sorumlu olacağı azami miktar belirlenmiş iken, garanti sözleşmesinde bu belirli değildir. Borcun son olarak ulaştığı miktar, garanti verenin sorumlu olduğu miktarı belirleyecektir. ${ }^{47}$

818 sayılı eski Borçlar Kanunu'nda gerçek kişilerin "kefalet" adı dışında kişisel teminat vermeleri halinde bu teminata kefalete ilişkin hükümlerin uygulanacağına dair bir hüküm yer almamaktaydı. 6098 sayılı Türk Borçlar Kanunu'nun 603. maddesiyle yeni bir düzenleme getirilmiş ve kefaletin şekline, kefil olma ehliyetine ve eşin rızasına ilişkin hükümlerin gerçek kişilerce, kişisel güvence verilmesine ilişkin olarak, başka ad altında yapılan diğer sözleşmelere de uygulanacağı öngörülmüştür. Madde gerekçesinde, kaynak İsviçre Borçlar Kanunu'nda olmayan bu düzenleme ile amaçlananın kredi sözleşmelerine kefil olan gerçek kişilerin "garanti” başlığını taşıyan düzenlemelerle daha korunaklı bir kurum olan kefaletin bertaraf edilmesinin önüne geçmek olduğu belirtilmiştir. ${ }^{48}$

TBK'nın 603. maddenin konuluş amacı (ratio legis) şu şekildedir: "Madde kefili koruyucu hükümlerden kurtulmak amacıyla başka adlar altında yaptıkları sözleşmelere de kefalet hükümlerinin uygulanacağını belirtmektedir. Böylece mesela kefalet sözleşmesi yerine üçüncü kişinin fiilini üstlenme sözleşmesi yapılmasında olduğu gibi alacaklıların kefili koruyucu hükümlerden kurtulmalarının ve bunlart dolanmalarının önlenmesi amaçlanmıştır."49

44 CANBOLAT, Ferhat, Banka Garantisinde Savunma İmkânları ve İhtiyadî Tedbirler, Ankara, 2009, s. 103; OLGAÇ, Senai, Kefalet, Ankara, 1987, s. 11

45 HATEMİ, Hüseyin, SEROZAN, Rona, ARPACI, Abdulkadir, Borçlar Hukuku Özel Bölüm, İstanbul, 1992, Filiz Yayınevi, s. 523

46 TANDOĞAN, s.818

47 ERDEN, Kuntalp, "Yargıtay Kararları Işı̆̆ında Kredi Kartı", Ticaret Hukuku ve Yargıtay Kararları Sempozyumu XIII, Ankara, 1996, s. 298; KIZILIRMAK, Cansu Kaya, "Revised Rules of Turkish Code of Obligations on Formal Requirements of Contract of Surety", Annales de la Faculte de Droit d'Istanbul, Cilt 48, Say1 65, s. 136. As1l borcun belirli olmaması halinde kefalet, sözleşme tarihine göre belirlenecek asıl borca göre hesaplanabileceği cihetle yine de geçerlidir. (GÜNDÜZ, Şefika Deren, 6098 Sayılı Türk Borçlar Kanunu'na Göre Kefalet Sözleşmesinin Şekli, İstanbul, 2015, s. 97)

48 KOCAMAN, 603. Madde, s.485

49 UYAP Mevzuat Programı, Erişim Tarihi: 03/04/2020 


\section{VI- TEMINAT SÖZLEŞMESINIIN YORUMU: BAŞVURULACAK ILKELER VE YARARLANILACAK KARINNELER}

\section{A- Temel Ayırt Edici Kriter: Aslilik-Fer'ilik}

Temel ayırt edici ölçüt budur. Fer'ilik varsa kefalet vardır. Kefaletle kefil, bir üçüncü şahsın yani asıl borçlunun borcunun ifasını güvence altına alır. Bu sebeple asıl borcun geçerliliği kefalet için önemlidir. ${ }^{50}$ Kefalet sözleşmesinin mukadderatı asıl borca bağlıdır; asıl borç iptal, dönme, geri alma gibi sebeplerle sona ererse kefalet de sona erer. ${ }^{51}$ Buna karş1lık, incelememize konu olan kefalet benzeri garanti sözleşmesinde garanti alan ile garanti veren arasındaki vaat, garanti alan ile üçüncü kişi arasındaki temel borç ilişkisinden her zaman bağımsızdır. Kefalet fer'i bir hak olarak asıl borca bağlı ve onun yanındaki bir haktır. Bu husus özellikle defileri ileri sürmede etkisini gösterir. $^{52}$

Kefaletin fer'i niteliğinden ancak şu şekilde yararlanılabilir. Yükümlülüğün fer'i olmadığı anlaşılırsa; yani, asıl bir diğer borca bağlılık söz konusu değilse, böyle bir güvence akdi kefalet değildir. Fakat taahhüt anında asıl bir borcun bulunmaması, fer'ilik olasılığını tamamen ortadan kaldırmayacaktır. Çünkü gelecekteki ve şarta bağlı borçlar için de kefalet söz konusu olabilmektedir. Bu şekildeki bir borca kefalet, fer'ilik ilkesine istisna getirmemektedir. Bu halde de kefilin sorumluluğu için sonradan asıl borcun doğmasi şarttır. ${ }^{53}$

BK'nın 485. maddesinde hata veya asıl borçlunun ehliyetsiz olması sebebiyle bağlayıcı olmayan bir sözleşmeden doğan borca kefil olan kişi, kefil olduğu sırada bu durumu biliyor idiyse, her ne kadar "kefalet benzeri garanti"den bahsedilmesi gerekirse de, madde hükmü uyarınca ancak "kefalet" hükümlerine göre sorumlu tutulabilir. Bu durum "zamanașımı" için de aynı şekildedir. 6098 sayılı TBK'da, eski BK'nın yer almayan ama kaynak İsviçre Borçlar Kanunu'nda var olan "zamanaşımı” konusuna yer verilmiştir. Özetle garanti veren, yükümlülük altına girdiğinde borcun zamanaşımına uğradığını biliyorsa artık kefalet benzeri garanti sözleşmesi değil, kefalet

50 OSER, Hugo/ SCHÖNENBERGER, Wilhelm, İsviçre Borçlar Kanunu Şerhi, Çeviren: SUNGURBEY, İsmet, Ankara, 1964, s. 93

51 ARAL, Fahrettin, AYRANCI, Hasan, Borçlar Hukuku Özel Borç İlişkileri, Ankara, 2015, Yetkin Kitabevi, s. 416; AYAN, Serkan, Kefalet Sözleşmesinde Kefilin Sorumluluğu, Ankara, 2013, s. 492, von TUHR, Andreas, Borçlar Hukuku Umumî Kısım, Cilt 1-2, Ceviren: Cevat EDEGE, Ankara, 1983, s. 662

52 KOCAMAN, Garanti mi; Kefalet mi? s.72

53 REISOĞLU, Garanti Mukavelesi, s.77 
sözleşmesi hükümleri uygulanacaktır. Kefalet sözleşmesinin garanti vereni daha koruyucu olduğuna değinilmişti. ${ }^{54}$

$\mathrm{Bu}$ arada şu hususu da belirtmek gerekir ki, hem kefalette hem garantide, kefil olunan veya garanti edilen asil borcun ifa edilmemesi durumunda ifa edilmeyen bu borç değil; kefalette alacaklının, garantide de garanti alanın bu sebeple maruz kaldığg zararın ödenmesi gerekecektir. ${ }^{55}$

\section{B- Teminat Sözleşmesinin Yorumu: Başvurulacak İlkeler ve Yararlanılacak Kriterler}

Yukarıda anılan temel ölçüte rağmen sözleşmenin niteliği tam olarak tespit edilemiyorsa veya tereddüt giderilemiyorsa, sorun "yorum" yöntemiyle açıklığa kavuşturulabilir. TBK'nın 19. maddesi 1şı̆̆ında, kişisel bir teminat verilmesine ilişkin bir sözleşmede, tarafların bu sözleşmeyi nasıl nitelendirdikleri önemli olmayıp, tarafların gerçek iradesi doğrultusunda nitelendirme yapılması gerekir. ${ }^{56}$ Bağımsız bir yükümlülük yüklenilmek istenildiği halde kefil olmaktan bahsedildiği gibi, kefilin "garanti ediyorum" demesine de uygulamada rastlanılmaktadır. ${ }^{57}$ Ölçütleri şu şekilde sıralanabilir:

Hâkim, sözleşmede taraflarca tercih edilen deyimlerle ve terimlerle bağlı kalmayarak TBK'nın 19. maddesi uyarınca sözleşmeyi tarafların gerçek ve ortak amaçlarını araştırarak o sözleşmenin hukuki nitelendirmesini yapar. ${ }^{58}$ Kefalet hukukuna hakim olan, yükümlülük altına giren kişinin korunması düşüncesinin gerçekleştirilmesi, tereddüt halinde kefaletin kabulünü zorunlu kılar. Kefalet lehine yapılan bu nitelendirme, "daha az olan yükümlülük lehine karine"ye de uygun düşer. Ancak bu sonuca ulaşmak için sözleşmenin lafzından, anlam ve amacından veya hal ve şartlardan başka şekilde bir sonuç çıkarılmasının mümkün olmaması gerekir. ${ }^{59}$ Şüpheli durumlarda kefalet vasıflandırmasının gerekliliği, kefalet kurumuna ilișkin emredici hukuk kurallarının bertaraf edilmesi kaygısıyla ilgilidir. Hâkim, şüphe halinde daha koruyucu olan kefalet nitelendirmesini tercih etmelidir. ${ }^{60}$

Bu konularda gerçek kişilere göre daha uzman olan bankaların garantiye dair ifadeleri ve yabanc1lık unsuru ihtiva eden sözleşmelerdeki güvenceleri,

54 KOCAMAN, 603. Madde, s.493

55 EREN, s. 779

56 ÖZEN, Burak, s.29

57 REISOĞLU, Kefalet, s. 125

58 TANDOĞAN, s.832

59 KOCAMAN, Garanti mi; Kefalet mi? s.74

60 BARLAS, Nami, Türk Hukuk Sisteminde Banka Teminat Mektupları, İstanbul, 1986, s.39 
karine olarak "garanti” sayılır. Bunun aksine, gerçek kişilerin verdikleri güvenceler daha çok "kefalet" kabul edilir. ${ }^{61}$

Güvenceye temel oluşturan sözleşmesel bir üçüncü borç ilişkisi de belirtmek gerekir ki sözleşmenin nitelendirmesi için yeterli değildir. Burada üçüncü borç ilişkisi ile güvence sözleşmesi arasındaki ilişkiye bakılmalıdır. Şu şekilde bir ayrım yapılabilir: Güvence verenin yükümlülüğü ile asıl borçlununki aynı ise; yani, güvence veren asıl borçlunun edasını amaçlamayıp sadece bunu teminat altına alıyorsa, taahhüt edilen edanın kendisi olup tazminat değilse ve eda taahhüdü ile asıl borçlunun taahhüdü örtüşüyorsa, burada daha çok kefaletin varlığından bahsedilmelidir. Her ikisi tamamen aynı ve birbirine bağl1 ise, bu kefalete işaret eder. ${ }^{62}$

Kefalet borçluya, garanti alacaklıya yöneliktir. Güvence sözleşmesinde edanın ayrıntılı ve bağımsız olarak tanımlanması garantiye işarettir. Şayet nitelendirme için akdi üçüncü borç ilişkisine başvurmak gerekiyorsa burada daha çok kefaletten bahsetmek gerekecektir. Kefilin ilgili borçlunun şahsına yönelmiştir. Garantide ise garanti veren bir sonuca ilişkin riski üstlenir. ${ }^{63}$

Kefalet bir yardım isteğinin sonucudur. Eğer temel borç ilişkisinden garanti verenin bir menfaati varsa burada daha çok kefaletten bahsetmek gerekir. Fakat bu kural her zaman geçerli değildir. Bu kuralın diğer kıstaslar 1şığında değerlendirilmesi gerekir. ${ }^{64}$ Kefil genellikle borçluya yardımcı olmak için karşıllısız şekilde finansal bir rizikoyu üstlenir. Oysa garanti veren aynı riski şahsi menfaatini korumak amacıyla üstlenmektedir. Fakat tabii ki teminat sözleşmesinin açık lafzından fer'i bir yükümlülük üstlenme niyeti çıkarılabildiği ölçüde "kefalet", kefilin şahsi menfaatini yasaklamaz. ${ }^{65}$

"İlk talepte ödeme" yükümlülüğü ve kaydı: Bu kayıt tek başına bir ölçüt değil, sadece bir emaredir. Zira sözleşmenin diğer kıstaslarla yorumlanması sonucu sözleşmenin niteliğine ilişkin farklı nitelendirme yapılabilir. ${ }^{66}$

Teminat sözleşmesinde güvence verenin güvence alanı tam olarak tatmin etmeden önce üçüncü şahsa rücû edemeyeceğine dair bir kayıt varsa, bu kefalete işaret eder; çünkü, rücû garanti sözleşmesiyle bağdaşmaz. ${ }^{67}$ Burada

61 KOCAMAN, Garanti mi; Kefalet mi? s.75

62 BILGEN, s. 118

63 BILLGEN, Mahmut, s. 118; KOCAMAN, Garanti mi; Kefalet mi? s.76

64 KARAHASAN, Mustafa Reşit, Türk Borçlar Hukuku Özel Borç İlişkileri, İstanbul, 2004, Beta Yayıncilik, s. 1204

65 KOCAMAN, Garanti mi; Kefalet mi? s.77

66 KOCAMAN, Garanti mi; Kefalet mi? s.77

67 KOCAMAN, Garanti mi; Kefalet mi? s.76 
"kontgaranti" kavramını da açıklamakta fayda vardır. Banka teminat mektuplarında bilindiği üzere banka garanti veren, muhatap garanti alan ve üçüncü kişi de edimi vaat edilen; yani lehdar kişidir. İşte bu üç köşeli hukuki ilişkide banka ile lehdar arasında bir kontgaranti sözleşmesi varsa, banka muhataba borcu ödedikten sonra lehdara rücu edemeyecektir. Bankanın, karşıladığı bu güvenceyi lehdardan sebepsiz zenginleşme hükümlerine göre talep edip edemeyeceği ise tartışmalıdır. ${ }^{68}$

Def'i ve itirazlardan kül halinde feragate ilişkin beyanlar asli, bağımsız bir güvenceye işaret eder. Bu husus aslında "ilk talepte ödeme kaydı" ile de ilgilidir. Nitekim, Yargıtay da birçok kararında "protesto çekilmesine, hüküm istihsaline, lehdarın rızasını almaya gerek olmadan muhatabın ilk talebinde ödeme taahhüdü” kayıtlarını içeren teminat mektuplarını garanti sözleşmesi olarak kabul etmektedir. ${ }^{69}$ Garanti verenin, garanti alana karşı üçüncü şahsa ait def'ileri ileri sürememesi, fer'iliğin ortadan kalktığını ve sözleşmenin garanti sözleşmesi olduğunu gösterebilir. ${ }^{70}$

\section{VII- YARGITAY HUKUK GENEL KURULUNUN 04/07/2001 GÜN, 2001/19-534 ESAS ve 2001/583 KARAR SAYILI İCTTIHADININ DEĞERLENDİRILMESI}

Dava konusu kredi kartıyla ilgili verilen teminatın hukuki niteliğine ilişkindir ve karar içeriğinde kefalet ile garanti sözleşmelerinin farkının ortaya konulmaya çalışıldığı cihetle önem arz etmektedir. Kararda özetle:

"Banka ile müşteri arasında yapılan "Bankomat-Kredili Bankomat" sözleşmesiyle, banka, kredi kartı hamili olan müşterisine belli limitler çerçevesinde kredi açarak kullandırması kabul etmiştir. Kart hamiline tahsis edilen kredi limit 2,5 milyar TL olarak belirlenmiştir.

Sözleşmenin son kısmında "Kredili Bankomat ve Kredi Kartı İçin Garanti Şerhi” başlığı altında şu hükme yer verilmiştir: "Bu sözleşmede yer alan hükümlere göre, müşteri veya ek kart hamillerinin yükümlülüklerini ve tüm borçlarını garanti ettiğimden işbu sözleşme ile tespit edilen banka kartı ve kredi kartı hesapları üzerine açılan kredi limitlerinin ve daha sonra da Banka tarafindan tek tarafl olarak garantörlügüum altında her yll Mart, Haziran, Eylül ve Aralık ayl sonlarında en fazla \%25'i oraninda

68 BİLGEN, Mahmut, s. 115

69 TANDOĞAN, s.824

70 KOCAMAN, Garanti mi; Kefalet mi? s.77

71 Kredi kartlarında kefalet, hem kredi kartı sözleşmesinin altının kefil sıfatıyla imza edilmesi, hem de müstakil bir kefalet sözleşmesi şeklinde yapılabilir. (KOSTAKOĞLU, Cengiz, Son Değişikliği ile Bankalar Kanunu Şerhi, İstanbul, 2004, s. 760) 
arttırabileceğini, müşteri velveya ek kart hamillerinin sözleşmedeki kredi limiti ve/veya arttırllan limitlerinden doğmuş doğacak tüm borçları ile fer'ilerini...kayltsı şartsı kabul ve garanti ettiğimi, bununla birlikte herhangi bir limite bağlı olmaksızın...ve kartların yenilenmesi, kaybedilmesi, çalınması, şifrenin deşifre edilmesi hallerinde doğacak borçlar da dahil olmak üzere Bankaca ödenmesi istenecek meblağlarl, protesto çekmeye... gerek olmaksızın ve borçlular ile Bankanı arasında ortaya çıkacak herhangi bir uyuşmazlı ve bunun akıbet ve kanuni neticelerini dikkate almaksızın Bankanızın ilk yazılı talebi üzerine derhal ve hiçbir sebep ileri sürmeksizin...ödemeyi...kabul ve garanti ederim..."

Sözleşmenin bir başka hükmünde ise, bankanın müşteriye tahsis ettiği kredi limitini arttırıp azaltabileceği, bu limit değişikliklerinin kart hamiline duyurulacağı, müşteri ve garantörün söz konusu limit değişikliklerini bilmedikleri iddiasında bulunamayacakları gösterilmiştir. Uyuşmazlık bu şerhin kefalet mi yoksa garanti mi olduğu noktasında ortaya çıkmaktadır.

Uyuşmazlık yargıya taşınmış ve Ödemiş 2. Asliye Hukuk Mahkemesi 21/12/1999 gün, 1999/279 E ve 1999/450 K sayılı ilamı ile anılan şerhin "kefalet" niteliğinde olduğunu belirtmiştir.

Temyiz üzerine dosyayı inceleyen Yargitay 19. Hukuk Dairesi ise 18/12/2000 gün, 2000/7170-8738 sayılı ilamı ile tarafların kefalet değil garanti sözleşmesi amaçladıklarını belirterek borçlunun sorumlu olduğu toplam borç miktarının belirlenmesini, sonra da limit aşımının kabul edilebilir ölçülerde olup olmadığını ve borcun artmasında bankanın bir kusurunun bulunup bulunmadığ 1 noktalarının araştırılarak, garanti verenin sorumlu olacağı miktarın belirlenmesini işaret ederek kararı bozmuştur.

İlk derece Mahkemesi ise direnme kararı vermiştir.

Bunun üzerine dosya Hukuk Genel Kuruluna (HGK) taşınmıştır.

HGK her iki sözleşmenin ayırt edilmesi için kullanılacak yardımcı ve ana kıstaslar üzerinde durmuştur. Anılan şerh beyanındaki terim ve deyimler dikkate alındığında ilk başta ortada bir garanti varmış gibi görünüyorsa da, sadece bu terimlerden hareketle bir sonuca varmanın, garanti ve kefalet arasındaki ölçütleri belirleyen 11/06/1969 gün ve 4/6 sayılı İçtihadı Birleştirme Kararı (IBBK) 1şığında, doğru olmayacağını belirtmiştir. Bu belirlemeden sonra ana kriterler üzerinde durulmuş ve garanti şerhinin kredi kartı sözleşmesinin "hemen altında" yer alması, beyanın başlangıcında da kredi sözleşmesine yollama yapılarak bu sözleşmeden doğan ve doğacak borçlar için davalıdan teminat beyanı alınmasının beyanın garanti değil kefalet 
amacına yönelik olduğu intibaının borçluya verilmiş olduğu kabul edilmiştir. $\mathrm{Bu}$ kapsamda, beyanın genel anlamından teminat verenin bağımsız bir borç değil kredi kartı müşterisi asıl borçlunun sorumluğunu yüklendiği ve böylece ikinci ana kıstas bakımından da bir garanti sözleşmesinin varlığından söz edilemeyeceğini ifade edilerek, teminat verenin bu sözleşmeyi yapmakta menfaati olduğunun belirlenememesi ve bu hususun davacı banka tarafından da ileri sürülüp kanıtlanmamış olması, teminatın, bağımsız, objektif bir amaca değil asıl borçlunun borçlarını karşılamaya yönelik olarak verilmesi karşısında davacının taahhüdünün BK'nın 18. maddesi uyarınca kefalet olarak kabul edilmesi gerektiği, yine, asıl kredi sözleşmesinde limitin belli olması ve garanti beyanında da bu sözleşmeye yollama yapılması nedeniyle kefaletin asli unsuru olan limit belirlemesinin gerçekleştiği hükme bağlanmıştır. Anılan HGK içtihadında oylamaya katılan 43 üyeden 11 'i bozma yönünde oy kullanmıştır. $^{72}$

Garanti ve kefalet arasındaki temel ayırt edici ölçüt aslilik ve fer'iliktir. Dava konusu sözleşmede "garanti şerhi”nde yer alan: "Bu sözleşmede yer alan hükümlere göre, Bankomat 724 kart hamili ve ortak kart hamillerinin yükümlülüklerini, doğmuş ve doğacak tüm borçlarını garanti ettiğinden..." ibaresi fer'iliğe ve dolayısıyla kefalete işaret eder. Daha önce açıklandığ 1 üzere, özellikle kefalet benzeri garanti sözleşmesinde de garanti alanın üçüncü şahısla arasındaki temel ilişkiye atıf yapılması sebebiyle, yapılan bu atıf, garanti ve kefalet sözleşmelerinin ayrımını her zaman net bir şekilde ortaya koymaz. Kefalet benzeri garanti sözleşmesi kefalete yaklaşmaktadır ama garanti alan ile üçüncü kişi arasında hiçbir "geçerli" temel ilişki şart koşulmaz. Dolayısıyla şerhteki metnin bu kısmı için kefalet sonucuna varmak çok mümkün değildir.

Teminat verenin eda yükümlülügü asıl borçlunun eda yükümlülüğü ile aynı ise; yani teminat veren asıl borçlunun edasını amaçlamıyor, aksine teminat altına alıyorsa, teminat veren asıl borçlunun ödememesi halinde tazminat değil, aksine sadece edayı taahhüt etmişse, onun eda taahhüdü asıl borçlunun taahhüdü ile karşıllk olarak örtüşüyorsa, daha ziyade kefaletin varlığı kabul edilmek gerekir. Teminat altına alınan eda ile temel ilişkideki edanın tamamen aynı oluşu ve birbirine bağl1lığ 1 , kefaletten söz edilmesine yol açar. Buradan hareketle de sözleşmedeki "garanti şerhi”" incelendiğinde

72 ARKAN, Sabih, Kredi Kartıyla İlgili Olarak Verilen Güvencenin Hukuki Niteliği (HGK'nın 4/7/2001 Tarihli Kararının Eleştirisi), Ünal Tekinalp'e Armağan, Cilt I, İstanbul 2003, Beta Kitabevi, s.983-985 
Ankara Üni. Hukuk Fak. Dergisi, 69 (2) 2020: 419-442 Garanti ve Kefalet Sözleşmeleri Arasındaki Ayrım...

bir ayniyet ve örtüşme görülmediği cihetle sözleşmenin niteliği belirlenememektedir. ${ }^{73}$

Aslilik ve fer'ilik kıstaslarıyla bir sonuca varılamaması durumunda ise sorun “yorum” yöntemiyle çözülmelidir. TBK'nın 19. maddesi uyarınca yorum yaparken sözleşmenin lafzı, anlam ve amacı, hal ve şartlar ve münferit beyanların içeriği dikkate alınıp, teminat sözleşmelerinin yorumunda da "güven ilkesi" 1şığında yol izlenmelidir. TBK'nın 19. maddesine göre bankanın bu metne vermek istediği anlam değil, güven ilkesi kapsamında tarafların ortak ve gerçek amaçları araştırılmalıdır. HGK anılan içtihadında, “...hiçbir menfaati olmayan, ticari gaye gütmeyen, sadece dostane ilişkiler nedeniyle tüketime yönelik banka kredi kartı kullanmasına imkân tanımak için verilen teminatı amacına aykır olarak yorumlanmasını yasanın yukarıda anılan hükmüne aykırılık teşkil eder..." demiştir. Yine HGK'nın bu içtihatta: "Garanti Şerhi beyanı ve bu beyanda kullanılan sözcük ve deyimleri fer'i kistaslardan olan sözleşmede kullanılan deyimler kistasına göre ilk bakışta bir garanti akdinin oluştuğu intibal birakiyor ise de, sadece bu deyim ve sözcüklere dayanılarak sözleşmenin niteliğinin belirlenmesi doğru olmayacağ gibi mümkün de değildir." demesiyle de isabetli bir yaklaşım gösterilmiştir. Yine anılan içtihatta belirtildiği gibi gerçek kişiler lehine verilen güvencenin daha çok kefalet olarak kabul edilmesi gerekir. ${ }^{74}$

Anılan içtihatta kullanılan bir diğer emare de "teminat veren kimsenin bu sözleşmeyi yapmakta menfaati olmaması" ölçütüdür. İçtihatta, İsviçre Federal Mahkemesinin bu yöndeki bir kararına atıf yapılmıştır. Bu ölçütün de her zaman uygulanabilir olduğunu söylemek zordur. Örneğin, bankalar da bazı durumlarda bankanın menfaati olmadan müssterileri lehine güvence vermektedirler. Taraflar menfaat unsurundan tamamen ari olarak verilen güvencenin kefalet mi yoksa garanti mi olduğunu belirleyebilirler. ${ }^{75}$

HGK içtihadındaki diğer bir emare de "kişiye yönelik teminat verme amacı"dır. İçtihatta: "Nihayet, kişiye yönelik teminat verme amacı gerek sözleşme, gerekse garanti beyanından açıkça anlaşılmaktadır. Zira verilen teminat kredi sözleşmesinin müşterisi ve asıl borçlusu Hüseyin isimli kişinin borçlarını karşılamaya yöneliktir. Bă̆ımsız ve objektif bir amaca yönelmiş değildir." denilmek suretiyle bu kıstas ortaya konulmuştur. Kefaletin borçluya, kefalet benzeri garantinin ise alacakliya yönelik olduğundan evvelce bahsedilmişti. Kefalet benzeri garanti sözleşmesinde garanti veren garanti

73 KOCAMAN, Garanti mi; Kefalet mi? s.79-80

74 KOCAMAN, Garanti mi; Kefalet mi? s.79-80

75 ARKAN, s.989 
alanın belli bir edayı elde etmesini garanti eder. $\mathrm{Bu}$ yüzden teminat sözleşmesinde edanın ayrıntılı olarak ve başlı başına, bağımsız olarak tanımlanması garantinin kararlaştırıldığ 1 şekilde bir karine teşkil eder. Buna karş1ık, garanti edilen edanın tespiti için tüm kapsamı itibariyle akdî üçüncü bir borç ilişkisine dayanmak gerekiyorsa, daha çok kefaletin varlığından bahsetmek gerekir. ${ }^{76}$

Bunların yanında, kefilin sorumlu olacağın miktarın gösterilmesi gerekir. HGK içtihadında 12/04/1994 gün ve 14/13 sayılı İBK'ye atıf yapmıştır. Atıf yapılan İBK'de kefalet sözleşmesinde gösterilmesi gereken miktarın niteliğiyle ilgili olarak özetle, kefalet senedinde yer alan bilgilerden limitin tespit edilebilir olmasının yeterli olduğu belirtilmiştir. HGK da buna istinaden asıl kredi sözleşmesindeki limitin belli olduğu cihetle, somut olayda kefaletin varlığına bir emare daha eklemiştir. ${ }^{77}$

Özetle, Yargitay HGK'nın 04/07/2001 gün, 2001/19-534 Esas ve 2001/583 Karar sayılı ilamındaki amacın kefili korumak olduğu da ortadadır. $\mathrm{Bu}$ içtihatla bankaların, başlı̆ğında "garanti" ifadesi kullanılan ve genel kayıtlar içeren sözleşmelerle kefili koruyucu hükümleri etkisiz kılması engellenmek amaçlanmıştır. ${ }^{78}$

Yargitay Hukuk Genel Kurulu benzer şekilde son olarak, 23/05/2019 gün, 2017/11-1731 Esas ve 2019/608 Karar say1l ilamında, yukarıda incelenen içtihadına atıf yaparak bunun müstakar olduğuna işaret etmiştir. ${ }^{79}$ Anılan kararın incelenmesinde dava tarihinin 22/09/2008 olduğu görülmektedir; yani 6098 sayılı Türk Borçlar Kanunu'nun yürürlük tarihi olan 04/02/2011'den öncedir. Her ne kadar Hukuk Genel Kurulu bu son ilâmında, önceki içtihadına atıf yapmışsa da, önceki kanun döneminde gerçekleşen olayların o kanuna göre çözülmesi gerektiğine işaret eden "kanunların geçmişe yürümemesi ilkesi" ${ }^{80}$ karşısında, 6098 sayılı Türk Borçlar

KOCAMAN, Garanti mi; Kefalet mi? s.83

ARKAN, s.990

KOCAMAN, 603. Madde, s.509

79 "Kişisel (şahsi) teminat sözleşmelerinin alt kavramlarını oluşturan kefalet ve garanti sözleşmelerinin temel amaçları, esas itibariyle asıl borç ilişkisinin tarafı olmayan üçüncü kişilerce, alacaklıya şahsi teminat (güvence) verilmesidir. Her iki sözleşme de temel amaçları itibari ile aynı hedefe yönelmekle birlikte, gerek doktrinde, gerekse bu konudaki uygulamanın öncüsü niteliğindeki 11.06.1969 tarihli ve 1969/4 E, 1969/6 K. sayılı Yargitay İçtihadı Birleştirme Kararındaki (YİBK) belirlemelere göre, her iki sözleşme arasında temel farklar bulunmaktadır. Nitekim, Yargitay Hukuk Genel Kurulunun 04.07.2001 tarihli ve 2001/19-534 E, 2001/583 K. sayılı kararında da her iki sözleşme arasındaki temel farklar belirtilmiştir..." UYAP Portal, Erişim Tarihi: 23/05/2020

80 KILIÇOĞLU, M. Ahmet, Medeni Hukuk Pratik Çalışmaları, Turhan Kitabevi, Ankara, 2018, Onbirinci Basıya Önsöz 
Kanunu'nun yürürlüğe girdiği tarihten sonra ortaya çıkan uyuşmazlıklarda, kefalet ve garanti sözleşmeleri arasındaki ayrımın yapılmasına ilişkin yorumda, 603. madde yol gösterici olacaktır. İşbu madde metninden de açıkça anlaşıldığ 1 üzere, artık gerçek kişilerce verilen kişisel güvenceye ilişkin sözleşme her ne ad altında olursa olsun, kefaletin şekline ilişkin hükümler uygulanacaktır.

\section{SONUÇ}

Kişisel teminatlar arasında yer alan her iki sözleşme türü ekonomik hayatta sıkça kullanılmakta ve ayrımı noktasında teorik olarak tartışmaları da beraberinde getirmektedir.

Kefalet sözleşmesi Kanun'da açıkça düzenlenmiş iken, garanti sözleşmesi TBK'nın 128. maddesi yardımıyla açıklanmaya çalışılmaktadır.

TBK'nın 603. maddesi ile “Kefaletin şekline, kefil olma ehliyetine ve eşin rızasına ilişkin hükümler, gerçek kişilerce, kişisel güvence verilmesine ilişkin olarak başka ad altında yapılan diğer sözleşmelere de uygulanır." hükmü getirilmiş ve önceki Kanun'da olmayan bir şekilde kefaletin uygulama alanını genişletmiştir.

Garanti sözleşmesinin unsurları, garanti alanı belli bir amaca yöneltmek amacı, garanti alanın hareket tarzından doğacak tehlikenin üstlenilmesi, bağımsız yükümlülük altına girme ve ivazsızlıktır.

Garanti sözleşmesi, yöneltmeyi amaçlayan; yani saf garanti sözleşmesi ve teminat amaçlı yani, kefalet benzeri garanti şeklinde temel olarak ikili bir ayrım şeklinde ortaya çıkmaktadır.

Kefaletten ayrılması güç olan da kefalet benzeri garanti sözleşmesidir.

Kefalette alacaklı ile borçlu arasındaki temel ilişkiye atıfta bulunurken, garanti sözleşmesinde bu şekilde bir yollama yer almamakta ve garanti veren garanti alan karşısında bağımsız bir borç altına girmektedir. Bu sebeple kefalet fer'i, garanti asli niteliktedir.

Aslilik-fer'ilik kıstasından hareketle sözleşmenin niteliği tespit edilemiyorsa, bu durumda yorum yöntemine başvurulur. Hâkim, sözleşmede taraflarca tercih edilen deyimlerle ve terimlerle bağlı kalmayarak sözleşmenin hukuki nitelendirmesini yapar. Bu sebeple tarafların kefalet veya garanti sözcüklerini kullanmalarının bir önemi yoktur. Sözleşmenin niteliği için kullanılan aslilik-fer'ilik kriteri ve yorum yönteminde kullanılan diğer kıstaslar her zaman doğru sonucu vermemektedir. Bu bakımdan, münferit duruma ait tüm hal ve şartların doğru değerlendirilmesi belirleyici olacaktır. 
Bununla birlikte, salt bu kriterler temel belirleyici unsur olamaz. TBK'nın 19. maddesi uyarınca ve "güven ilkesi" kapsamında tarafların ortak ve gerçek amaçları değerlendirilmelidir. Yine, kefalet hukukuna hakim olan, "yükümlülük altına giren kişinin korunması" ilkesinden hareket ederek, şüphe halinde sözleșmenin kefalet olduğu kabul edilmelidir.

\section{KAYNAKÇA}

ACAR Özlem, Türk Borçlar Hukukunda Müteselsil Kefalet Sözleşmesi, XII Levha Kitapçıllk, s.38

ARAL Fahrettin, AYRANCI Hasan, Borçlar Hukuku Özel Borç İlişkileri, Ankara, 2015, Yetkin Kitabevi

ARAT Ayşe, “Tüketici Hukukunda Kefalet Sözleşmesi”, Selçuk Üniversitesi Sosyal Bilimler Meslek Yüksekokulu Dergisi, Cilt 19

ARKAN Sabih, Kredi Kartıyla İlgili Olarak Verilen Güvencenin Hukuki Niteliği (HGK'nın 4/7/2001 Tarihli Kararının Eleştirisi), Ünal Tekinalp'e Armağan, Cilt I, İstanbul 2003, Beta Kitabevi, s.983-985

AYAN Serkan, Kefalet Sözleşmesinde Kefilin Sorumluluğu, Ankara, 2013

AYBAY Aydın, "Kefilin Önce Dava Def'ini İleri Sürmesi Sorunu”, Prof. Dr. Selim Kaneti’ye Armağan, İstanbul, 1996, s. 83-90

BARLAS Nami, Türk Hukuk Sisteminde Banka Teminat Mektupları, İstanbul, 1986

BARLAS Nami, "Kredi Kartı İlişkisinde Bankaya Karşı Verilen Teminatın Niteliğinin Belirlenmesi”, Ömer Teoman’a 55. Yaş Günü Armağanı, Cilk III, İstanbul, 2002

BİLGE Necip, Borçlar Hukuku Özel Borç Münasebetleri, Ankara, 1971

BİLGEN Mahmut, Öğreti ve Uygulamada Kefalet ve Yargılama Hukukuna İlişkin Uyuşmazlıklar, Adalet Yayınevi, Ankara, 2013, s.115

CANBOLAT Ferhat, Banka Garantisinde Savunma İmkânları ve İhtiyadî Tedbirler, Ankara, 2009

ÇEKER Mustafa, "Tüketicinin Korunması Hakkında Kanun Kapsamında Kredi Kartı Borcunun Ödenmemesi ve Hukuki Sonuçları”, Atatürk Üniversitesi Hukuk Fakültesi Dergisi, Cilt VIII, Sayı 1-2, 2004, s. 415-442

DEVELİOĞLU Hüseyin Murat, Kefalet Sözleşmesini Düzenleyen Hükümler Işığında Bağımsız Garanti Sözleşmeleri, Vedat Kitapçılık, İstanbul, 2009 
Ankara Üni. Hukuk Fak. Dergisi, 69 (2) 2020: 419-442 Garanti ve Kefalet Sözleşmeleri Arasındaki Ayrım...

ERDEN Kuntalp, "Yargıtay Kararları Işı̆ı̆ında Kredi Kartı", Ticaret Hukuku ve Yargitay Kararları Sempozyumu XIII, Ankara, 1996

EREN Fikret, Borçlar Hukuku Özel Hükümler, Yetkin Kitabevi, Ankara, 2009

GÜMÜŞ Alper, Borçlar Hukuku Özel Hükümler, Cilt II, İstanbul, 2014

GÜNDÜZ Şefika Deren, 6098 Sayı1ı Türk Borçlar Kanunu'na Göre Kefalet Sözleşmesinin Şekli, İstanbul, 2015

HATEMI Hüseyin, SEROZAN, Rona, ARPACI, Abdulkadir, Borçlar Hukuku Özel Bölüm, İstanbul, 1992, Filiz Yayınevi

İŞGÜZAR Hasan, Banka ve Kredi Kartı Sözleşmeleri, Yetkin Yayınları, Ankara, 2003

KAHYAOĞLU Emin Cem, Banka Garantileri, İstanbul, 1996, Beta Yayınları

KARAHASAN Mustafa Reşit, Türk Borçlar Hukuku Özel Borç İlişkileri, İstanbul, 2004, Beta Yayıncilik

KILIÇOĞLU M. Ahmet, Medeni Hukuk Pratik Çalışmaları, Turhan Kitabevi, Ankara, 2018

KIZILIRMAK Cansu Kaya, "Revised Rules of Turkish Code of Obligations on Formal Requirements of Contract of Surety" Annales de la Faculte de Droit d'Istanbul, Cilt 48, Say1 65, s. 133-149

KOCAMAN Arif, Türk Borçlar Kanunu'nun 603. Maddesi Üzerine Bir Değerlendirme-Kefalete İlişkin Hükümlerin Uygulama Alanı, Prof. Dr. M. İlhan Ulusan'a Armağan, Seçkin Kitabevi, Cilt 3, s.483-510

KOCAMAN Arif, Yargitay Hukuk Genel Kurulunun 4/7/2001 Tarih ve E.2001/19534, K.2001/583 Sayılı Kararı Üzerine Bir Değerlendirme- Kredi Kartı İlişkisinde Bankaya Karşı Verilen Kişisel Teminatın Hukuki Niteliği: Garanti mi; Kefalet mi? s.67-84

KOSTAKOĞLU Cengiz, Son Değişikliği ile Bankalar Kanunu Şerhi, İstanbul, 2004

OLGAÇ Senai, Kefalet, Ankara, 1987

OSER Hugo/ SCHÖNENBERGER Wilhelm, İsviçre Borçlar Kanunu Şerhi, Çeviren: SUNGURBEY, İsmet, Ankara, 1964

ÖZEN Burak, Kefalet Sözleşmesi, Vedat Kitapçılık, İstanbul 2014

REİSOĞLU Seza, Garanti Mukavelesi, Ajans-Türk Matbaası, Ankara, 1963

REİSOĞLU Seza, Türk Kefalet Hukuku, Ankara, 2013

ŞAHAN Gökhan, Kefalet Sözleşmesinin Sona Ermesi, Ankara, 2009 
TANDOĞAN Haluk, Borçlar Hukuku, Özel Borç İlişkileri, Cilt II, Vedat Kitapçılık, İstanbul 2010

\section{UYAP Mevzuat Programı}

\section{UYAP Portal}

von TUHR Andreas, Borçlar Hukuku Umumî Kısım, Cilt 1-2, Çeviren: Cevat EDEGE, Ankara, 1983

YAVUZ Cevdet, Borçlar Hukuku Özel Hükümler, İstanbul, 2016, Beta Yayıncılık

ZEVKLİLER Aydın, Borçlar Hukuku Özel Borç İlişkileri, Ankara, 2004 